\title{
Correction to: A local input-to-state stability result w.r.t. attractors of nonlinear reaction-diffusion equations
}

\author{
Sergey Dashkovskiy ${ }^{1} \cdot$ Oleksiy Kapustyan $^{2} \cdot$ Jochen Schmid $^{1,3}$
}

Published online: 21 July 2021

(c) The Author(s) 2021

\section{Correction to:}

Mathematics of Control, Signals, and Systems (2020) 32:309-326 https://doi.org/10.1007/s00498-020-00256-w

The article "A local input-to-state stability result w.r.t. attractors of nonlinear reactiondiffusion equations" written by Sergey Dashkovskiy, Oleksiy Kapustyan, and Jochen Schmid, was originally published online on 6 May 2020, without Open Access. After publication in volume 32, issue 3, page 309-326 the author decided to opt for Open Choice and to make the article an Open Access Publication. Therefore, the copyright of the article has been changed to (C) The Author(s) 2021 and the article is forthwith distributed under the terms of the Creative Commons Attribution 4.0 international License, which permits use, sharing, adaptation, distribution and reproduction in any medium or format, as long as you give appropriate credit to the original author(s) and the source, provide a link to the Creative Commons licence and indicate if changes were made. The images or other third-party material in this article is included in the article's Creative Commons licence, unless indicated otherwise in a credit line to the material. If material is not included in the article's Creative Commons licence and your intended use is not permitted by statutory regulation or exceeds the permitted

The original article can be found online at https://doi.org/10.1007/s00498-020-00256-w.

\footnotetext{
$\bowtie$ Jochen Schmid

jochen.schmid@itwm.fraunhofer.de

Sergey Dashkovskiy

sergey.dashkovskiy@mathematik.uni-wuerzburg.de

Oleksiy Kapustyan

alexkap@univ.kiev.ua

1 Institute for Mathematics, University of Würzburg, 97074 Würzburg, Germany

2 Kiev National Taras Shevchenko University, 01033 Kiev, Ukraine

3 Fraunhofer Institute for Industrial Mathematics (ITWM), 67663 Kaiserslautern, Germany
} 
use, you will need to obtain permission directly from the copyright holder. To view a copy of this licence, visit http://creativecommons.org/licenses/by/4.0.

Open Access This article is licensed under a Creative Commons Attribution 4.0 International License, which permits use, sharing, adaptation, distribution and reproduction in any medium or format, as long as you give appropriate credit to the original author(s) and the source, provide a link to the Creative Commons licence, and indicate if changes were made. The images or other third party material in this article are included in the article's Creative Commons licence, unless indicated otherwise in a credit line to the material. If material is not included in the article's Creative Commons licence and your intended use is not permitted by statutory regulation or exceeds the permitted use, you will need to obtain permission directly from the copyright holder. To view a copy of this licence, visit http://creativecommons.org/licenses/by/4.0/.

Publisher's Note Springer Nature remains neutral with regard to jurisdictional claims in published maps and institutional affiliations. 